\title{
Strategy to fulfill primary school students' information needs in the digital era
}

\author{
Tria Nur Aisyah ${ }^{1}$ and Kiki Fauziah, ${ }^{2, *}$ \\ ${ }^{1}$ Undergraduate student. Department of Library and Information Science, Universitas Indonesia, \\ Depok, West Java - 16424, Indonesia \\ ${ }^{2}$ Department of Library and Information Science, Universitas Indonesia, Depok, West Java - 16424, \\ Indonesia
}

\begin{abstract}
This study discusses the strategy of meeting the needs of information on primary school students in the digital age. The purpose of this study is to identify the strategy to fulfil the information needs of primary school students in the digital era today. This research uses a qualitative approach with case study method. Data collection was done by interview and document analysis. The results of this study indicate that the strategy of fulfilling the information needs of the students of SDN Bendungan Hilir 12 are first through the printed book and then if the printed book does not meet the needs of the information then the students use the internet as a medium in finding information to meet the information needs. Also, when students get information over the internet, to verify the truth of the information, they ask the nearest person who is trusted by the student.
\end{abstract}

\section{Introduction}

In today's digital age, information becomes one of the primary needs of every individual. Pendit [1] argues that information needs is a necessity to fill a particular void in man, that is, in the state of his lack of knowledge. In other words, a person can be said to need information when he realises his lack of knowledge to solve a particular problem. The information needs of each vary depending on the individual's interests, status, and work. Individual information needs will grow as their age increases. Nicholas [2] describes many factors that affect information needs, some of which consist of: (1) occupation; (2) personality, they are the psychological aspect of the information seeker, includes accuracy, persistence in seeking information, systematic search, motivation and willingness to receive information from friends, colleagues or superiors; (3) time; (4) access, i.e the extent to which tracing information internally (within the organization), or external (outside the organization); and (5) resources of information technology used to seek information. As well as there will be differences in information needs between children with parents; students with teachers; students with lecturers; and so forth.

\footnotetext{
* Corresponding author: kikifauziah@ui.ac.id
} 
A child generally has a higher curiosity about the environment and the surrounding world. Currently, strategies for meeting children's information needs, change from previous generations due to the development of technology experienced by children, especially for primary school students. Latrobe and Havener in Agosto and Hughes-Hassell [3] identified six categories of student information are (a)course-related activities (b)current lifestyles, (c)plan, (d)relationships with others, (e)health, and (f)general information. In today's digital era, primary school students in Jakarta are beginning to change curriculum that further implements technology in the process of teaching and learning. This is evident from the curriculum changes; from the Education Unit Level Curriculum (known as KTSP) to Curriculum 2013 (known as K13). The student-centred curriculum 2013 requires children to be more actively involved in meeting the information needs of their learning materials in

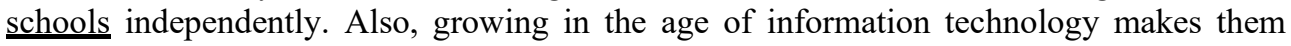
more familiar with using a variety of sources and formats of information. This is evident from the results of a survey conducted by Hottest Insight in 2013 which states that $40 \%$ of children in Indonesia are technologically literate or also called active internet users [4]. Likewise with the results of a survey conducted by the Association of Internet Service Providers Indonesia (APJII) in 2016, that 768,000 children aged 10-14 years in Indonesia has become an active internet user [5].

SDN Bendungan Hilir 12, from now on abbreviated as SDN Benhil 12, is one of the flagship state primary schools in DKI Jakarta located in Tanah Abang Subdistrict. The object of learning in this study is primary school students in grade 4, 5 and 6 . Researchers chose them because their information needs begin to increase and becoming more various. Their ability to understand the contents of the message in a wealth of information was good enough. Besides, they are also able to operate information technology such as smartphones and computers.

In the current digital era, it is important to educate students in using information from internet wisely. This is related to the importance of skills related to students' understanding in information needs and the right strategies in meeting the information needs. If the development of technology is accompanied by the right skills in using information tailored to the information needs of each individual, it is hoped that it can be long life learning for students in solving problems of their daily lives.

Previous research related to the information needs of students has been widely studied. The research is related to the information needs of children, especially primary school students by Chang, Liu, Tsai, \& Fan [6], which explain about information needs and information seeking behaviour of primary school students in Taiwan. The results of this study indicate that students need information to complete the task of teachers, support school lessons, and to increase knowledge about personal interests or hobbies. The information sources that are used by students are textbooks, information from parents, television, libraries and the internet.

Another research on the information needs of primary students has also been done in 2009 by Fuad Gani [7] entitled "Information Needs of Primary Students in Jakarta". This research used a quantitative approach to the subject of private primary school students in five areas of Jakarta, and its object is the need for reading materials and their behaviour concerning the library. The result of this research is that almost all primary school students who become respondents of this research know library even though not all schools have library; the most favored subjects are science and mathematics; primary school students much prefer folklore and translated story; and in contrary, puppet stories to be less desirable subjects by them. Most of the textbooks that they need are gotten by buying it or borrow them from libraries and friends.

Based on these two previous studies, this research focuses more on the strategy of meeting the information needs of primary school students in the digital era, i.e. students of 
SDN Bendungan Hilir Jakarta. The purpose of this study is to identify the strategy for meeting the information needs of primary school students in the digital age.

\section{Method}

This research uses a qualitative approach with case study method. The case study method is conducted where researchers investigate a program, event, activity, process, or group of individuals carefully [8]. The reason for using the qualitative approach is to gain an indepth understanding of the strategies that primary school students perform in the digital age in meeting the information needs. This research was conducted at the Library of SDN Bendungan Hilir 12 which located at TM Bendungan Jatiluhur Street, Tanah Abang, Central Jakarta. This research started from February 2018 until April 2018.

The object of research is the 4th, 5th, and 6th grade primary school students. Researchers chose them to become the object of research based on their various and increased information needs. Their ability to understand the contents of the message in a piece of information was already good enough. Moreover, they are also able to operate information technology such as smartphones and computers. The selection concept on informants is using purposive sampling method with criteria, i.e. students who have frequent visits to the school library more than seven times a month; have the ability to tell their own experiences or provide which information they need; are willing to be informants in the study; and have enough time to interview.

The data collection is done by interview, observation, and document analysis. The general questions in the interviews submitted to the informants in this study are the information they need, the strategies they do in meeting the information needs and the obstacles they face in meeting them. Analysis of the documents that are used in this study is a list of library visitors as a tool in selecting informants and data collection owned by the SDN Benhil 12 library to look at the suitability of school library collections with the information needed.

\section{Discussion}

\subsection{Student information needs at SDN Benhil 12}

Based on the results of research, the information needs of students of SDN Benhil 12 are information about activities related to lessons (academic), lifestyle, plans, relationships with others, health and general information.

Table 1. Student information needs.

\begin{tabular}{|l|l|}
\hline Activities & Information Needs \\
\hline Academics & $\begin{array}{l}\text { Information related to lessons such as adding reference material, doing the tasks } \\
\text { from the teacher and preparing for the exam. }\end{array}$ \\
\hline
\end{tabular}




\begin{tabular}{|l|l|}
\hline Lifestyles & $\begin{array}{l}\text { Information related to history, science, sports and entertainment (games, toys, } \\
\text { dances, cartoons, and music). }\end{array}$ \\
\hline Plans & $\begin{array}{l}\text { Information related to their plans for the next level of education, junior high } \\
\text { school. }\end{array}$ \\
\hline $\begin{array}{l}\text { Relationships } \\
\text { with others }\end{array}$ & information about what attitude they should have done in dealing with something. \\
\hline Health & Information about the types of illness and drugs. \\
\hline $\begin{array}{l}\text { General } \\
\text { Information }\end{array}$ & \begin{tabular}{l} 
Information related their hobbies, schools, sports, and realtionships. \\
\hline
\end{tabular}
\end{tabular}

Based on the data obtained by the researchers about the information needs, related to the lessons of the informants, it revealed that they need information related to the lesson to finish the tasks (art, culture lessons and workshops). Plus, add the reference subjects that the material in the school book less support (religion, social science, mathematics) and to prepare the future for the exam, the contest and the grade promotion. This is in line with what Shenton \& Dixon [9] discloses that for high-grade students (grades 4th, 5th, and 6th), academic skills become important and their needs on subjects that support the curriculum are increasingly diverse. What is interesting about this finding is that students also need lessons that are not available in their education curriculum, which is English. From this, it can be seen that the library should be keen on curriculum changes and student needs. Although a subject has been abolished, it turns out that student interest in the particular subject is still high. So, the library is expected to providing collection and library program to meet the needs of these students. Information related to the lifestyle in this research is like activities that are influenced by the interests of each informant such as sports, movies, hobbies or other entertainment. Of the various opinions, expressed by the informants, they have some interests on lifestyle, such as history, science, sports and entertainment (games, toys, dances, cartoons, and music). Thus, it can be seen that their needs not only in the form of printed books or electronic but also the physical collecti on of those. Furthermore, they also need library programs to play with them. Libraries can provide programs for children's play, especially with educational games. Children can also be introduced to traditional Indonesian toys. So that, not only can play they also can get to increase their knowledge.

\subsection{The strategy to fulfill SDN Benhil 12 students' information needs}

Based on the results of the interview, it was seen that there were various kinds of different strategies applied by students in fulfilling their information needs. The following table meets students' information needs. 
Table 2. The strategy to fulfill students' information need.

\begin{tabular}{|c|c|c|c|c|c|c|}
\hline $\begin{array}{c}\text { Informas } \\
\text { nts }\end{array}$ & Academice & Life Style & Plans & $\begin{array}{l}\text { Relationship } \\
\text { with others }\end{array}$ & Health & $\begin{array}{c}\text { General } \\
\text { Information }\end{array}$ \\
\hline Vinca & 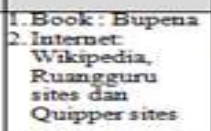 & $\begin{array}{l}\text { 1. School } \\
\text { Library } \\
\text { 2.RPIPA } \\
\text { 3. Rnternet } \\
\text { Yourube }\end{array}$ & Parents & Internet & $\begin{array}{l}\text { 1. Taevision } \\
\text { 2. Google }\end{array}$ & Television \\
\hline Junior & $\begin{array}{l}\text { 1. Book Bupena } \\
\text { 2. Internet Wikip } \\
\text { edia }\end{array}$ & $\begin{array}{l}\text { TV Channe : } \\
\text { NVational } \\
\text { Geographic, } \\
\text { Discovery } \\
\text { Channel }\end{array}$ & $\begin{array}{l}\text { 1. Paremts } \\
\text { 2. Book }\end{array}$ & Internet & Google & Television \\
\hline Hasan & $\begin{array}{l}\text { 1. Book: Bupena } \\
\text { Interenet } \\
\text { Yourube }\end{array}$ & 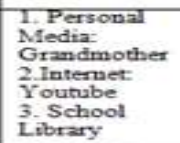 & $\begin{array}{l}\text { Personal } \\
\text { Media }\end{array}$ & $\begin{array}{l}\text { 1. Book } \\
\text { 2. Internet }\end{array}$ & Google & Television \\
\hline Arsya & $\begin{array}{l}\text { 1. Book: Bupena } \\
\text { 2.1nternet } \\
\text { Brainly. } \\
\text { wikipedia } \\
\text { 3. Parents }\end{array}$ & $\begin{array}{l}\text { 11nternet } \\
\text { Instagram, } \\
\text { Youtube }\end{array}$ & $\begin{array}{l}\text { Friends } \\
\text { Parents }\end{array}$ & $\begin{array}{l}\text { Internet } \\
\text { Instagramm }\end{array}$ & $\begin{array}{l}\text { Internet } \\
\text { Instagram }\end{array}$ & $\begin{array}{l}1 \\
2 \\
2 . \text { Gookgle }\end{array}$ \\
\hline Zedy & $\begin{array}{l}\text { 1. Book Bupena } \\
\text { 2. Intemet } \\
\text { Brainlyet } \\
\text { W.ikipedia } \\
\text { 3. Parents }\end{array}$ & $\begin{array}{l}\text { 1.Y Youtube } \\
\text { 2. Book }\end{array}$ & Internet & $\begin{array}{l}\text { Internet } \\
\text { Instagram }\end{array}$ & Television & Television \\
\hline Gita & $\begin{array}{l}\text { 1. Book: Bupena } \\
\text { - Intermet Wakip } \\
\text { edia }\end{array}$ & Youtube & Parents & Internet & Telecision & Television \\
\hline
\end{tabular}

Based on table 2, it can be seen that the student strategy in fulfilling the information needs is different. To fulfil the needs of academic information, first, they access information through printed media. The book takes precedence in the school library. When library books are not available, they search the bookstore. However, when the book does not meet the needs of its academic information, students seek information via the internet on sites, believed to be valid of information providers such as Wikipedia, Ruang Guru, Quipper, Brainly, and Youtube. Based on the results of interviews, pre-students already have knowledge related to the usefulness of each site accessed. For example, Youtube is used to search for videos that can support their understanding of academic information. There were some informants who, when receiving information on the internet, also confirmed the information to parents or grandmothers that according to them could be an appraiser of the truth of the information received from the internet.

In the strategy of meeting the information needs related to plans, the students prefer to ask parents or grandmother or discuss with their peers. This shows that students still entrust information from parents to planning their future. Although today, information is widely available on the internet, for student decision-making regarding plans still prioritises the role of parents or grandmother as valid information for them. This differs in strategy in meeting the information needs related to the lifestyle, health, general, and relationships with others. The students prefer to seek information through TV channel or internet, such as Youtube and Instagram. This shows that students prefer to get formatted video information. According to them, the information in the form of videos is easier to understand than text. TV Channel that they access in fulfilment of information needs are Discovery, National Geographic, and dr. OZ which they deem will provide complete and valid information. This indicates that the students have basic knowledge in accessing the site or TV channel that is used as media in fulfilling the information needs.

\section{Conclusion}

Based on the data, the strategy of fulfilling the information needs of students is different depending on the type of information. Information related to the academic field of the 
students prioritises the source of information through printed books. While other information such as health, lifestyle, general, and relationships with other people prioritise the Internet as a medium in meeting the needs of such information. To fulfil the information needs of plans, students prefer to ask adults or peers. Thus, it can be concluded that in today's digital era, students still need printed books as the primary source in meeting their academic information needs. The use of the internet through gadgets is only used for tertiary information needs. Not only that, the results of the study also show students still need the role of parents, peers or people who are more mature in making decisions for their plans.

\section{Acknowledgements}

This research is funded by Hibah PITTA 2018 from Directorat of Research and Community Engagement, Universitas Indonesia No. 1957/UN2.R3.1/HKP.05.00/2018.

\section{References}

1. P.L. Pendit, Makna informasi: lanjutan dari sebuah perdebatan, Kepustakawanan Indonesia: Potensi dan Tantangan (Kesaint Blanc, Jakarta, 1992)

2. D. Nicholas, Assessing Information Needs: Tools, Techniques And Concepts For The Internet Age (2nd Ed.) (Aslib, London, 2000)

3. E.D. Agosto, S. Hughes-Hassell, Journal of the American Society for Information Science and Technology 57, 1394 (2006)

4. P.Y. Wulandari, Anak asuhan gadget, Liputan 6, May $15^{\text {th }}$. Retrieved from http://m.liputan6.com/amp/246030/anak-asuhan-gadget?espv (2016)

5. N. Ngazis, T. Haryanto A, Data internet Indonesia, pengguna anak-anak mengejutkan. Retrieved rom http://m.viva.co.id/amp/digital/digilife/838794-data-internet-indonesiapengguna-anak-anak-mengejutkan?espv=1 (2018)

6. C. Chang, S. Liu, C. Tsai, J. Fan, Information needs and information seeking behaviors of elementary school students in taiwan-interviewed with xin sheng \& wan fang elementary schools (2007)

7. F. Gani, Kebutuhan informasi siswa sd Jakarta (Universitas Indonesia, Depok, 2009)

8. W.J. Creswell, Research Design: Pendekatan Kualitatif, Kuantitatif, Dan Mixed (Pustaka Pelajar, Jogjakarta, 2010)

9. K.A. Shenton, P. Dixon, Library and Information Research 28, 25 (2004) 